\title{
ТЕХНІЧНІ ЗАСОБИ НАВЧАННЯ УКРАЇНСЬКОЇ МОВИ
}

\begin{abstract}
У статті окреслено причини, щзо зумовлюють потребу в дослідженні дидактичних засобів навчання української мови, визначено мету, враховано дані сучасних досліджень учених про застосування традиційних $і$ новітніх засобів навчання мови та досвід роботи в загальноосвітній школі, обтрунтовано значущість правильного комплексного відбору засобів залежно від навчально-виховних завдань і навчального матеріалу, з'ясовано поняття засобів навчання української мови, названо основні засоби навчання, компоненти, функиії, завдання, виділено сутнісні характеристики традиційних і новітніх технічних засобів навчання, виявлено вимоги до технічних засобів навчання в реалізації завдань сучасного уроку української мови, визначено ефективні технічні засоби навчання мови (візуальні - sтs-повідомлення, кодоскоп, діапозитиви, діапроєктори, відеопроєктори, електронні посібники, підручники, енциклопедії; аудитивні магнітофонні записи мовленнєвих висловлювань (монологів, діалогів, трилогів, полілогів, діалогічних єдностей, реплік), платівки, радіо, телефон; аудіовізуальні - комп'ютер, Інтернет, мультимедійні проєктори, звукові кінофільми, діафільми, відеофільми, відеофрагменти, відеопрезентація, мультфільми), виокремлено окрему групу допоміжних технічних засобів, що об 'єднують засоби малої автоматизаиії та апарати для допоміжних иілей (радіомікрофон, електронні дошки, світлові й електронні таблиці, відеокамери, фонограма, диктофон, електронна пошта, пристрої дистанційного керування комплексами ТЗН), висвітлено ефективні технічні засоби навчання мови, шоо сприяють успішному вивченню і засвоєнню матеріалу, активізащії пізнавальної діяльності, розвитку соціально значущих рис, загальнолюдських моральних якостей $і$ компетентностей школярів, проаналізовано роль дидактичного матеріалу для технічних засобів (спроєктовані ситуативні завдання, моделі діалогів; тексти-зразки з навідними запитаннями; початкові стимулювальні репліки, репліки-реакиії), а також наочності для технічних засобів (фото, тематичні слайди, картини, малюнки, таблииі, схеми, моделі об'єктів, ілюстрачії), сформульовано висновки та перспективи подальших наукових розвідок.

Ключові слова: засоби навчання украӥнської мови, щуо забезпечують розвиток мовної особистості учня, засоби вдосконалення комунікативних умінь і навичок, технічні засоби.
\end{abstract}

Однією з вимог Концепції державної політики у сфері реформування загальної середньої освіти “Нова українська школа" є створення сучасного освітнього середовища, яке забезпечить умови, технології і засоби для навчання учнів. 3 метою досягнення освітніх цілей і успішної самореалізації школярів учитель-словесник має орієнтуватися в нових процесах сучасної школи, підходах до змісту та структури уроку, оволодіти методикою оптимального застосування не тільки традиційних та інноваційних методів і прийомів, а й ефективних засобів навчання української мови, що забезпечують розвиток мовної особистості учня і формування комунікативної компетентності особистості.

Метою статті $є$ визначення засобів навчання української мови, обгрунтування ефективності застосування технічних засобів навчання української мови як матеріальних джерел інформації, що полегшують організацію навчального процесу, забезпечують пізнавальну активність школярів, удосконалюють комунікативні вміння і навички.

Визначенню ефективних засобів навчання мови приділяли увагу О. Біляєв, М. Вашуленко, О Горошкіна, С. Караман, І. Кочан, Л. Кравець, Л. Мамчур, Е. Палихата, М. Пентилюк, Т. Симоненко, А. Фасоля. Дослідники трактують засоби навчання як “предмети, що викликають сенсомоторні стимули (впливають на зір, слух, дотик тощо) і полегшують учням пізнання дійсності [1, с. 124]”, як “будь-які прилади, обладнання та устаткування, що використовуються для передавання інформації у процесі навчання [2, с. 51]”, як “сукупність необхідних матеріальних, предметних, звукових, образних і словесних реальностей та уособлень, ідей та певних дій, що є обов'язковою умовою реалізації поставленої особистісно орієнтованої мети в навчальновиховному процесі [3, с. 45]". На нашу думку, для точного визначення засобів навчання української мови необхідно спиратися на наукові розвідки М. Пентилюк, яка називає матеріальні засоби навчання (підручники, посібники, таблиці, збірники вправ, текстів, словники, звукозаписи, технічні) і доводить, що засоби складаються з трьох компонентів: 1) навчального матеріалу, що складає зміст навчання (мовні поняття і терміни, що входять до шкільної програми, їх визначення, правила, приклади мовних одиниць, ужитих у текстах вправ і завдань, тексти для аналізу); 2) методів і прийомів навчання, спрямованих на засвоєння мовної теорії і формування комунікативних умінь і навичок; 3) організації навчально-виховної роботи (екскурсії, позакласні та позашкільні заняття, самостійні домашні завдання, проєкти, презентації тощо) [4, с. 56]. У зв’язку 3 цим можемо стверджувати, що засоби навчання мови - це допоміжні опори, що забезпечують грунтовність знань, логічність операцій, пізнавальну активність, самостійність учнів згідно з мовними, мовленнєвими та соціокультурними аспектами вивчення. На думку вчених (Н. Захлюпана, І. Кочан, М. Пентилюк), основними засобами, що можуть впливати на збагачення матеріально-джерельного аспекту методів навчання української мови, є дидактичний матеріал (слова, словосполучення, речення, тексти для аналізу; картки із запитаннями, завданнями, вправами; методичні посібники для вчителя, словники; ілюстрації і репродукції картин для бесід і творів), наочність (демонстраційні, порівняльні, узагальнювальні, опорні, текстові, словникові, динамічні таблиці, таблиці-схеми, моделі, картини, малюнки), технічні засоби (комп’ютер, магні- 
тофон, радіопередачі, телепередачі, грамзапис, відеофільми) [6, с. 93], [4, с. 56]. Усі засоби виконують такі завдання: проілюструвати теоретичні положення; сприяти успішному розвитку мовних і мовленнєвих умінь та навичок, збагаченню інтелектуальної й емоційної сфери учнів; формувати духовну мовну особистість [7, с. 57]. Слід зазначити, що засоби (допоміжні опори) також удосконалюють комунікативні вміння і навички школярів, дають змогу створити ситуацію спілкування згідно з метою навчання, сприяють активності, самостійності, засвоєнню соціальних норм, цінностей. Тому, досліджуючи засоби вдосконалення комунікативних умінь і навичок, Л. Мамчур справедливо підкреслює такі функції: не тільки створення, але й видозміну ситуацій спілкування; надання зразків мовленнєвих жанрів і зразків мовленнєвої поведінки [3, с. 47]. Е. Палихата стверджує, що засоби вдосконалення комунікативних умінь і навичок повинні однозначно, оглядово й естетично відображати суттєве; описувати ситуацію спілкування таким чином, щоби співрозмовникам неможливо було не говорити; мати методичну основу; подаватися зрозуміло й доступно; слугувати реалізації мети навчання процесу діалогування; бути науково обгрунтованими; досягати максимально високої методичної ефективності при мінімальних економічних затратах [5, с. 157 ]. Серед запропонованих дослідницею засобів, що сприяють продукуванню висловлювань, виділимо вербальні - штучні ситуації, початкові стимулювальні репліки, тексти; візуальні - діапозитиви, ілюстрації та їхні серії, малюнки, картини, інтерактивна дошка, схеми; вербально-візуальні-моделі діалогічних текстів із навідними завданнями, діалогічні репліки з навідними завданнями, ілюстрації та вербально описані ситуації; аудіювальні - магнітофонні записи мовленнєвих висловлювань - монологів, діалогів, трилогів, полілогів, діалогічних єдностей, реплік, платівки, стимулювальні запитання; аудіовізуальні - комп’ютер, звукові кінофільми, діафільми, кодоскоп, відеофільми, відеофрагменти; природні ситуації - життєві ситуації, що дають змогу схвалити, засудити, виправдати під час створення діалогічних (полілогічних) висловлювань із використанням мовномовленнєвого матеріалу.

Безсумнівно, якість сучасного уроку української мови неможлива без організованого застосовування визначених засобів, що забезпечать розвиток мовної особистості учня і формування комунікативної компетентності кожного учасника процесу навчання. Проте в оновленні та модернізації мовної освіти особливу роль відіграють технічні засоби як сукупність пристроїв із дидактичним забезпеченням. За цілями, дидактичним призначенням технічні засоби поділяють на мотиваційно-пізнавальні (створюють емоційний настрій, викликають інтерес до виучуваного матеріалу, спонукають до самостійної діяльності), проблемні (створюють умови для виникнення проблемної ситуації, активізують пізнавальну діяльність), навчальні (виступають джерелом нових знань); за видом сприйняття: звукові- вплив на слухові органи (магнітофони, музичні центри, програвачі), екранні - вплив на органи зору (діапроєктори, кінопроєктори, графопроєктори, відеопроєктори), екранно-звукові - вплив на органи зору і слуху (телевізори, Інтернет, відеомагнітофони) [8, с. 3]. За способом впливу технічних засобів на учнів визначено візуальні - sms-повідомлення, кодоскоп, діапозитиви, електронні посібники, підручники, енциклопедії; аудитивні - магнітофонні записи мовленнєвих висловлювань (монологів, діалогів, трилогів, полілогів, діалогічних єдностей, реплік), платівки, радіо, телефон, фонограма; аудіовізуальні - комп'ютер, Інтернет, мультимедійні проєктори, звукові кінофільми, діафільми, відеофільми, відеофрагменти, мультфільми. Класифікації дали змогу вченим трактувати технічні засоби навчання як сучасне обладнання навчального процесу, що впливає на зорові, слухові аналізатори учнів, реалізує принципи наочності, емоційності в навчанні, посилює інтерес учнів до навчання 3 метою підвищення ефективності навчального процесу [4, с. 124].

У дослідженні виділяємо окрему групу допоміжних технічних засобів, що об'єднують засоби малої автоматизації і апарати для допоміжних цілей: радіомікрофон, електронні дошки, світлові й електронні таблиці, відеокамери, диктофон, електронна пошта, пристрої дистанційного керування комплексами ТЗН. Система цих засобів наведена на рис. 1.

Важлива роль дидактичного матеріалу для застосування технічних засобів безперечна. Вимоги до дидактичного матеріалу (забезпечувати всі принципи навчання, виховні й пізнавальні завдання шкільного курсу мови; бути бездоганним стосовно норм літературної мови, лексичного багатства мови та різноманітності форм; мати в своїй основі зв'язний текст) допомагають доцільно впроваджувати технічні засоби навчання з метою досягнення задекларованих освітніх завдань. Визначивши специфіку й значущість текстів інтернетсередовища, Л. Кравець справедливо визначає текст ефективним засобом навчання мови в комп'ютерних програмах, що дають змогу створювати й змінювати різноманітні тексти, шукати й переглядати фрагменти, конвертувати кодування символів, працювати у вікі (гіпертекстовій збірці документів) й вебі (інтернет-просторі) тощо [5, с. 32].

Аналізуючи тексти різних стилів, типів, жанрів мовлення, їх зміст, структуру та мовні засоби, учні засвоюють його комунікативні якості (роль у спілкуванні), стилістичну належність та функції мовних одиниць, а отже, формують і вдосконалюють свою мовну й мовленнєву компетенції. Аналіз структурно-смислової єдності тексту, мовних засобів зв'язку між його окремими реченнями є підгрунтям якісних, комунікативно доречних власних висловлювань, що репрезентують зв'язне мовлення і забезпечують спілкування. На текстах-зразках (монологах, діалогах, полілогах) учитель може продемонструвати зміст і структуру спілкування, ознайомити учнів із вербальними й невербальними засобами мовлення, показати їхню відповідність цілям, умовам ситуації, прогнозувати, моделювати ситуацію спілкування. Крім того, аналіз довершених, 


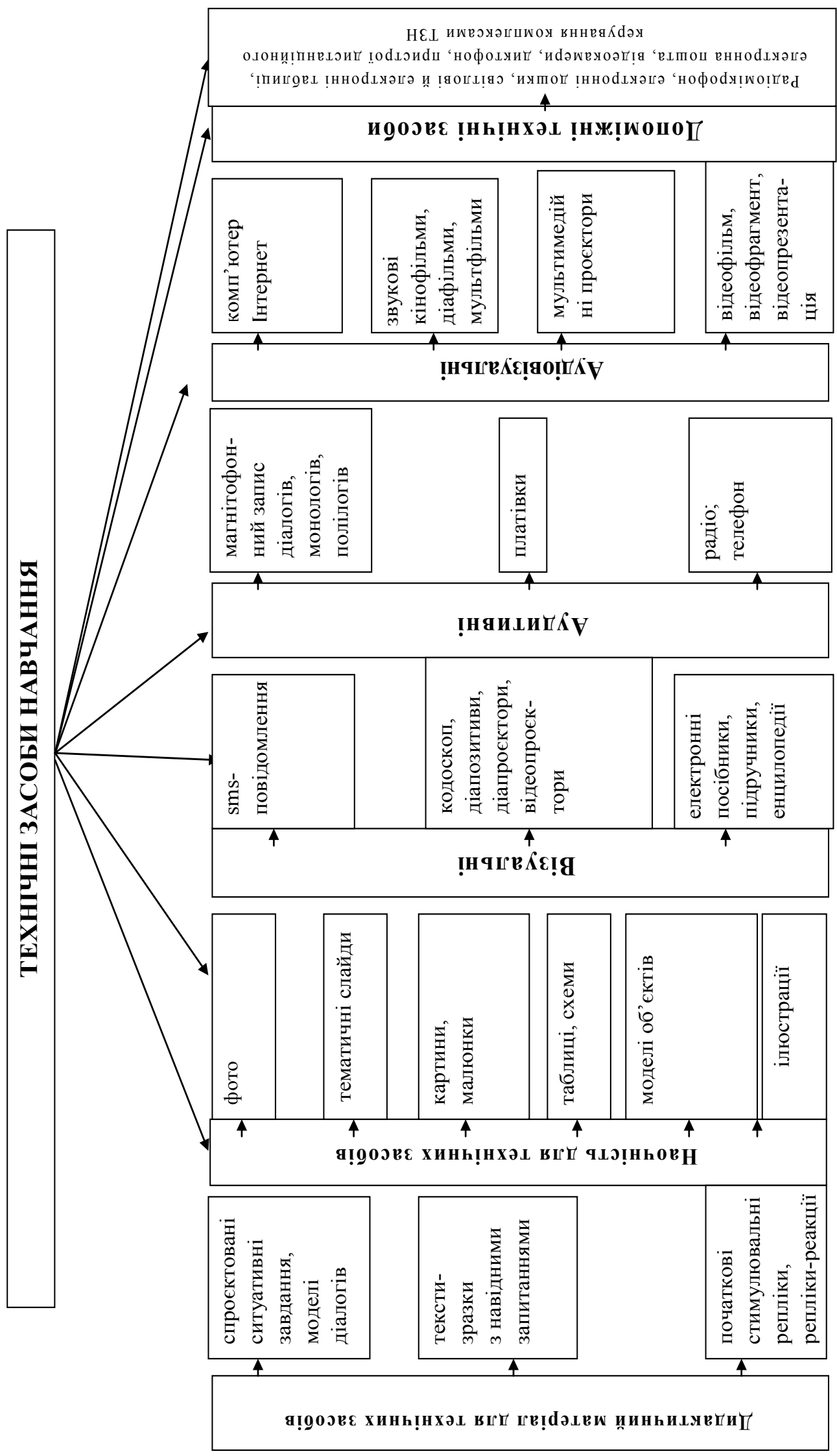


високохудожніх зразків словесної творчості позитивно впливає на процес продукування висловлювань учнів, розвиток емоційного інтелекту та мовленнєвої культури в різних ситуаціях, виховує естетичні смаки, відповідальність за свої мовленнєві дії.

До засобів формування мовленнєвих і комунікативних умінь на уроках української мови О. Глазова, Т. Донченко, Е. Палихата, Н. Подлевська, Л. Шевцова, Г. Шелехова та ін. відносять спроєктовані ситуативні завдання. Е. Палихата справедливо стверджує, що мовленнєві ситуації дають змогу “активізувати розмовні формули, відповідну лексику, граматичні структури, не фіксуючи увагу на них, будять уяву учнів, примушуючи їх правильно оформлювати свою думку [9, с. 92] Навчальна ситуація (наприклад, побудувати діалог, відредагувавши тексти етикетних повідомлень засобами sms-спілкування) зумовлює ту чи іншу реакцію 3 метою навчання, природна (наприклад, обговорення події, що відбулася в класі, школі, державі чи за іiі межами) дає змогу проаналізувати життєву проблему, штучна (уявіть продовження розмови) - мотивує учнів при створенні уявного діалогу. Виконуючи їх, учні вчаться орієнтуватися в умовах спілкування, планувати, створювати та коригувати власні висловлювання відповідно до ситуації, добирати мовні засоби. За допомогою таких завдань учитель спонукує учнів до роздумів, пошуку рішень, формує навички мовленнєвого етикету, виробляє внутрішню потребу говоріння, розвиває необхідність у самореалізації.

Комп’ютерна техніка дає змогу учневі активно взаємодіяти 3 динамічними таблицями, опорними схемами-моделями, сигналами й алгоритмами, картинами, малюнками, ілюстраціями та їхніми серіями, тематичними слайдами, що є об'єктами логічних операцій, засобом пошуку інформації, матеріалом для створення власних висловлювань, самостійних висновків. Найпоширенішим засобом вивчення української мови є демонстраційні таблиці, що часто служать ілюстрацією до відповідного матеріалу.

Актуальним є застосування на уроках української мови візуальних технічних засобів (електронні підручники, посібники, енциклопедії, діапозитиви, діапроєктори, кодоскоп, відеопроєктори). Інтерактивні (електронні) підручники дають змогу самостійно навчатися в режимі моментального самоконтролю та корекції якості знань. Визначивши переваги використання електронного підручника (максимальний рівень наочності, комплексність сприймання інформації всіма видами аналізаторів, інтерактивність, пристосування до індивідуальних потреб учня, можливість організації дистанційної допомоги та самонавчання, дистанційного навчання, мобільність), Ю. Барановська, Ю. Балаховська трактують електронний підручник як дидактично доцільний, методично наповнений і технічно досконалий мультимедійний навчальний ресурс, який забезпечує організовану вчителем або самостійну навчальну діяльність учня з певного предмета [10, с. 3]. На думку Л. Скуратівського, електронний підручник як підручник-тренажер і комплекс словесно-логічних і матричних моделей опорних схем, таблиць, планів, блоку методик і тренінгів творчого стимулювання, мовленнєвого розвитку дає змогу істотно розширити в учнів можливості самостійного використання зразків додержання правил спілкування, виконаних засобами мультиплікації або ж у вигляді фрагментів ігрових фільмів, наведенні анімаційних чи ігрових зразків, виконаних однолітками, ситуативних діалогів, зразків проведення дискусій з певної проблеми, зразків комунікативних ситуацій для визначення комунікативної проблеми, що спонукує учнів до розв'язання, активізації асоціативних зв'язків, мислення, уяви, пам'яті. Учений зазначає значущість у навчальному процесі й електронного посібника як засобу роботи з учнями, які належать до різних груп, розподілених за рівнями пізнавальних можливостей школярів.

Діапозитиви (транспаранти та слайди), що демонструються за допомогою діаскопів, епідіаскопів, кадропроєкторів, є ефективним засобом для ознайомлення з новим матеріалом, заочних екскурсій під час проведення нетрадиційних уроків тощо; відеопроєктори, діапроєктори, проєктори для комп'ютерних презентацій допомагають відтворити зображення тексту, малюнка, фотографії, унаочнюють матеріал для спостережень і висновків, сприяють розвитку пізнавальних інтересів, свідомому засвоєнню знань.

Магнітофонний запис текстів, грамзаписи, аудіозаписи належать до аудитивних технічних засобів, що формують правильність висловлювань школярів, удосконалюють навички слухати, аналізувати інформацію, поважати альтернативну думку, прагнути до діалогу, висловлювати точку зору, аргументувати й дискутувати, уникати конфліктів, шукати компроміси, контролювати мовленнєву поведінку.

Поряд із традиційно відпрацьованими технічними засобами навчання звукового та зорового сприйняття (магнітофон, програвач тощо) у практиці сучасної школи використовують аудіовізуальні технічні засоби, серед яких виділяємо комп'ютер, що “матеріалізує” мовленнєву наочність за допомогою звукових, колірних, графічних форм, динаміки зображення тощо, створює необхідну для занять мовну ситуацію, залучає учнів до активної взаємодії з динамічними таблицями, опорними схемами, сигналами й алгоритмами.

С. Караман охарактеризував створюване мовне середовище в комп'ютері можливістю керування навчальною діяльністю учня як учителем, так і самим учнем; активністю (навчальна діяльність учня відбувається в процесі взаємодії з комп'ютером); динамічністю (ситуація, в якій учень розв'язує навчальні завдання, змінюється залежно від цілей, умов і перебігу навчання); проблемністю (перед учнем комплекс взаємопов'язаних проблем, які повинен розв'язати); природністю (спілкування відбувається за умов комунікативної ситуації, імітованої на екрані у формі природного людського діалогу між учнем і комп'ютером) $[11$, с. 124]. Л. Скуратівський пояснює ефективність комп'ютера як інноваційного засобу навчання застосуванням нового принципу комунікації, що виявляється в організації діалогу між комп'ютером і суб'єктом пізнання, у процесі якого учень одержує підказки та поради щодо виходу зі складної ситуації під час вико- 
нання пізнавального завдання, планування подальших мовленнєвих дій [12, с. 9]. Такий вид роботи допомагає активізувати пізнавальну діяльність, підвищити рівень якості знань, умінь і навичок учнів, поглибити їх та вдосконалити під час самостійної роботи, поліпшити контроль та самоконтроль на основі зворотного зв’язку, відпрацювати навички спілкування. Крім того, на рівні змісту навчальної діяльності комп'ютер може показати результат формальної операції, імітувати ситуацію з реальним об'єктом, на рівні ж відтворення - продемонструвати хід міркувань, у процесі якого учень може порівняти еталонне рішення 3 власним для досягнення оптимального варіанту.

Серед технічних засобів навчання на базі інформаційних комп'ютерних технологій виокремлюють Інтернет. Костенко I. Г. стверджує, що за допомогою мережі Інтернет можна реалізувати дидактичні й соціокультурні завдання: формування навичок читання; удосконалення навичок писемного мовлення, умінь і навичок аудіювання на основі звукових текстів, монологічного і діалогічного мовлення на основі проблемного обговорення матеріалів мережі, збагачення словникового запасу школярів; ознайомлення 3 мовним етикетом, особливостями мовної поведінки в умовах спілкування, особливостями культури мови [13, с. 171]. Додамо, що активне застосування інформаційно-комунікаційних технологій забезпечує контроль якості знань, умінь і навичок, індивідуальний підхід до учнів, розвиток критичного мислення, емоційного інтелекту, формує життєві компетентності, потрібні для успішної самореалізації, суб'єкт - суб'єктної взаємодії всіх учасників навчального процесу. Основними дидактичними можливостями Інтернет-технологій є: 1) транспортування необхідної інформації, 2) повсякденне та професійне спілкування; 3) безпосереднє використання у навчально-виховному процесі [8, с. 3]. Взаємодія з Інтернет-технологіями (філологічні, лінгвістичні Інтернет-сайти, онлайн-ресурси, вебсторінка мовознавця, електронний словник, довідник, електронний журнал, електронна газета, електронна пошта, проєкти, презентація, аудіозапис текстів у виконанні майстрів слова, відеоконференція) сприяє компетентно-діалогічному наповненню мотиваційної, змістової, операційної сторін комунікативної й пізнавальної діяльності через заохочення взаємодії в спілкуванні, розв'язання творчих завдань і проблемних ситуацій. Мультимедіа-технології дають змогу здійснювати поєднання в одному програмному продукті різноманітних видів інформації - традиційних (тексти, таблиці, ілюстрації, фото тощо) й оригінальних (звук, музика, фрагменти відеофільмів, анімація та інші ефекти), що стимулює комунікативну та пізнавальну активність учнів у процесі продукування висловлювань, забезпечує комплексний вплив вправ на учня, різноманітної інформації у вигляді друкованого тексту, живої мови, статичної і динамічної наочності при підтримці взаємодії учня з комп’ютером, моделює реальні комунікативні ситуації, долає протиріччя між мовою як засобом природного спілкування, пізнанням навколишнього світу та штучністю традиційного навчального середовища [11, с. 129]. Аудіовізуальні засоби (кінофільми, діафільми) служать джерелом нової інформації, зацікавлюють учнів, дають змогу ознайомити школярів із взірцями усних висловлювань, створювати різноманітні життєві ситуації щодо продуктивності й комфортності спілкування. Відеоматеріали (відеофільми та відеофрагменти), що забезпечують звуко-зоровий синтез, дають змогу спостерігати за мовленнєвою поведінкою співрозмовників, аналізувати зразки усних текстів різних стилів мовлення.

Отже, зміст та організація сучасного уроку української мови залежать від продуманого комплексного відбору й використання технічних засобів залежно від навчально-виховних завдань і виучуваного матеріалу, що сприяють успішному вивченню і засвоєнню матеріалу, активізації пізнавальної діяльності, розвитку соціально значущих рис, загальнолюдських моральних якостей і компетентностей школярів. Перспективи подальшого дослідження вбачаємо у визначенні й обгрунтуванні ролі інформаційно-комунікаційних технологій, що регулюють стосунки між співрозмовниками, розвивають емоційну та інтелектуальну сфери, створюють умови для мовленнєвої взаємодії.

Використана література:

1. Гончаренко С. Український педагогічний словник, Київ: Либідь, 1997. 376 с.

2. Термінологічний словник з основ підготовки наукових та науково-педагогічних кадрів післядипломної педагогічної освіти / за наук. ред. Є.Р. Чернишової. Київ: ДВНЗ “Університет менеджменту освіти”, 2014. 230 с.

3. Мамчур Л. Основні засоби забезпечення розвитку комунікативних умінь учнів на уроках рідної мови. Aзимут научных исследований: педагогика и психология. № 1. 2014. С. 45-48.

4. Словник-довідник з української лінгводидактики: навч. посіб. / за ред. М. Пентилюк. Київ: Ленвіт, 2003. 149 с.

5. Кравець Л. Інформативність електронного тексту. Дивослово. 2017. № 1. С. 32 - 35.

6. Захлюпана Н.М., Кочан І.М. Словник-довідник з методики викладання української мови. Львів: Видавничий центр ЛнУ ім. Івана Франка, 2002. 250 с.

7. Практикум з методики навчання української мови / за ред. М.І. Пентилюк. Київ: Ленвіт, 2003. 302 с.

8. Терещенко Т., Романов О., І. Козинець Методичні рекомендації щодо використання в навчальному процесі засобів навчання. Дніпропетровськ: ДДФА, 2006. 17 с.

9. Палихата Е.Я. Методика навчання українського усного діалогічного мовлення учнів основної школи: монографія. Тернопіль, 2002. $271 \mathrm{c}$.

10. Балаховська Ю., Романенко Ю. Вимоги до електронних підручників української мови та літератури в умовах дистанційного навчання. Украӥнська мова і література в школі. № 2. 2020. С. 2-7.

11. Методика навчання української мови в середніх освітніх закладах / за ред. М. І. Пентилюк. Київ: Ленвіт, 2004.400 с.

12. Скуратівський Л. Інформаційні технології як засіб мовленнєвого розвитку учнів у процесі навчання української мови в основній школі. Українська мова і література в школі. 2005. № 4. С. 7-10.

13. Костенко І. Використання Інтернет-ресурсів на уроках англійської мови. Таврійський вісник освіти, 2013. № 1. С. $170-176$. 


\section{References:}

1. Honcharenko S. Ukrainskyi pedahohichnyi slovnyk [Ukrainian pedagogical dictionary]. Kyiv: Lybid, 1997. 376 s. [in Ukrainian]

2. Terminolohichnyi slovnyk z osnov pidhotovky naukovykh ta naukovo-pedahohichnykh kadriv pisliadyplomnoi pedahohichnoi osvity [Terminological dictionary on the basics of training scientific and scientific-pedagogical staff of postgraduate pedagogical education] / za nauk. red. Ye. R. Chernyshovoi. Kyiv: DVNZ "Universytet menedzhmentu osvity", 2014. 230 s. [in Ukrainian]

3. Mamchur L. Osnovni zasoby zabezpechennia rozvytku komunikatyvnykh umin uchniv na urokakh ridnoi movy [Main means of ensuring the students' communicative skills development in the lessons of their native language]. Azymut nauchnykh issledovanyi: pedahohyka y psykholohyia. № 1. 2014. S. 45-48. [in Ukrainian]

4. Slovnyk-dovidnyk z ukrainskoi linhvodydaktyky: navch. posib. [Reference Dictionary on the Ukrainian Language Didactics] / za red. M.Pentyliuk. Kyiv: Lenvit, 2003. 149 s. [in Ukrainian]

5. Kravets L. Informatyvnist elektronnoho tekstu [Electronic text information capability]. Dyvoslovo. 2017. № 1. S. 32-35. [in Ukrainian]

6. Zakhliupana N. M., Kochan I. M. Slovnyk-dovidnyk z metodyky vykladannia ukrainskoi movy [Reference Dictionary on Methods of Teaching the Ukrainian language]. Lviv: Vydavnychyi tsentr LNU im. Ivana Franka, 2002. $250 \mathrm{~s}$. [in Ukrainian].

7. Praktykum z metodyky navchannia ukrainskoi movy [Workshop on Methods of Teaching the Ukrainian language] / za red. M. I. Pentyliuk. Kyiv: Lenvit, 2003. 302 s. [in Ukrainian]

8. Tereshchenko T., Romanov O., I. Kozynets. Metodychni rekomendatsii shchodo vykorystannia v navchalnomu protsesi zasobiv navchannia [Guide on the use of teaching aids in the educational process]. Dnipropetrovsk: DDFA, 2006. 17 s. [in Ukrainian]

9. Palykhata E.Ya. Metodyka navchannia ukrainskoho usnoho dialohichnoho movlennia uchniv osnovnoi shkoly: monohrafiia [Methods of teaching Ukrainian oral dialogic speech to primary school students: a monograph]. Ternopil, 2002.271 s. [in Ukrainian]

10. Balakhovska Yu., Romanenko Yu. Vymohy do elektronnykh pidruchnykiv ukrainskoi movy ta literatury v umovakh dystantsiinoho navchannia [Requirements for electronic textbooks of Ukrainian language and literature in terms of distance learning]. Ukrainska mova i literatura $v$ shkoli. № 2. 2020. S. 2-7. [in Ukrainian]

11. Metodyka navchannia ukrainskoi movy $\mathrm{v}$ serednikh osvitnikh zakladakh [Methods of teaching the Ukrainian language in secondary schools] / za red. M.I. Pentyliuk. Kyiv: Lenvit, 2004. 400 s. [in Ukrainian]

12. Skurativskyi L. Informatsiini tekhnolohii yak zasib movlennievoho rozvytku uchniv u protsesi navchannia ukrainskoi movy $\mathrm{v}$ osnovnii shkoli [Information technologies as a means of students' speech skills development in the process of teaching the Ukrainian language in primary school]. Ukrainska mova i literatura v shkoli. 2005. № 4. S. 7-10. [in Ukrainian]

13. Kostenko I. Vykorystannia Internet-resursiv na urokakh anhliiskoi movy [Use of the Internet resources in English language lessons]. Tavriiskyi visnyk osvity, 2013. № 1. S. 170-176. [in Ukrainian]

\section{Zaitseva V. V., Yaremchuk N. S. Technical means of teaching the Ukrainian language}

The article outlines topical reasons for the Ukrainian language didactic teaching aids research. The main objectives are thoroughly defined; the data of contemporary studies of traditional and modern teaching aids use are taken into consideration. The research also discusses the experience of secondary school teaching process. The work reveals the importance of proper comprehensive selection of tools depending on educational tasks and study material, and clarifies the concept of Ukrainian language teaching aids. Besides that, the basic teaching aids, components, functions and assignments are named, the essential characteristics of traditional and newest technical teaching means are singled out, the requirements to technical teaching aids in realization of tasks of a modern Ukrainian language lesson are outlined (visual-sms-messages, overhead projector, slides, slide projectors, video projectors, electronic manuals, textbooks, encyclopedias; audial - tape recordings of speech utterances (monologues, dialogues, trilogues, polylogues, dialogic units, remarks), records, radio, telephone; audiovisual - computer, the Internet, multimedia projectors, sound films, filmstrips, video films, video clips, video presentation, cartoons); a peculiar group of auxiliary technical means which combine small automatic devices (radio microphone, electronic boards, light and electronic tables, video cameras, phonograms, dictaphone, e-mail, remote control devices of TME complexes) is indicated; The article highlights effective technical means of language learning, those which contribute to the successful study and mastery of material, as well as to facilitation of cognitive activity, development of socially significant traits, universal moral qualities and competencies of students. The role of didactic material for technical educational means (designed situational tasks, dialogue models; sample texts with leading questions, initial stimulus remarks, remarks-reactions) is analyzed; visual aids for technical means (photos, thematic slides, pictures, drawings, tables, diagrams, models of objects, illustrations) are discussed. The article highlights effective technical means of language learning, those which contribute to the successful study and mastery of material, as well as to facilitation of cognitive activity, development of socially significant traits, universal moral qualities and competencies of students. The role of didactic material for technical educational means (designed situational tasks, dialogue models; sample texts with leading questions, initial stimulus remarks, remarks-reactions) is analyzed; visual aids for technical means (photos, thematic slides, pictures, drawings, tables, diagrams, models of objects, illustrations) are discussed. The results of the research are summed up in conclusions and prospects for further scientific studies.

Key words: key means of teaching the Ukrainian language, which ensure student's language personality development, means of improving communication skills, technical means. 